\title{
PENGGUNAAN MEDIA ANIMASI PADA PEMBELAJARAN PAI UNTUK MENINGKATKAN MOTIVASI BELAJAR TUNAGRAHITA
}

\author{
Nilna Azizatus Shofiyyah \\ Fakultas Tarbiyah dan Keguruan, UIN Sunan Gunung Djati Bandung \\ ashofiyyahnilna@gmail.com \\ Asep Nursobah \\ Fakultas Tarbiyah dan Keguruan, UIN Sunan Gunung Djati Bandung \\ kangasnur@gmail.com \\ Tarsono \\ Fakultas Tarbiyah dan Keguruan, UIN Sunan Gunung Djati Bandung \\ tarsonomakmuri@yahoo.co.id
}

\begin{abstract}
The purpose of this study to explain the validation, implementation, factors, and effectiveness of animation media products in Islamic Religious Education Learning to improve learning motivation for children with developmental disabilities in SLB Angkasa Lanud Sulaiman. This type of research is a qualitative case study approach, taking place in SLB Angkasa Lanud Sulaiman. The results showed: 1) The validation of animated media products in Islamic learning PAI material was 94.1 and 91.4 If converted into an evaluation table the results of expert trials included in the "very good" criteria. 2) Implementation of PAI learning using animation media follows the steps made in the learning implementation plan. 3) Supporting factors that influence the learning of PAI using animation media are the ease of the animation media themselves to be used and the display of animated media which makes intellectual children easily understand the PAI material delivered, such as the pillars of Islamic principles. The inhibiting factor is the cost to access the animation media. 4) The level of success is shown in the value of mentally disabled students through reports on learning outcomes for mentally retarded students who get an average value of 80 of minimal completeness criteria of 75 .
\end{abstract}

Keywords; Islamic education, mentally retarded, media animation.

Abstrak: Tujuan pada penelitian ini adalah menguji validasi, impelemntasi, faktor-faktor, dan efektivitas Media Animasi dalam Pembelajaran Pendidikan Agama Islam dalam meningkatkan motivasi belajar Tunagrahita di SLB Angkasa Lanud Sulaiman. Jenis penelitian ini adalah kualitatif dengan pendekatan studi kasus, mengambil lokasi di SLB Angkasa Lanud Sulaiman. Hasil penelitian menunjukkan: 1) Validasi produk media animasi pada pembelajaran PAI materi rukun Islam yaitu 94,1 dan 91,4 Jika dikonversikan kedalam tabel penilaian hasil uji coba ahli termasuk pada kriteria "sangat baik". 2) Implementasi pembelajaran PAI menggunakan media animasi mengikuti langkah-langkah yang dibuat di dalam rencana pelaksanaan pembelajaran. 3) Faktor pendukung yang mempengaruhi

(C) Author et al, Licensee Psychosophia, Islamic Psychology Program, IAIN Syaikh Abdurrahman Siddik Bangka Belitung, Indonesia. Psychosophia strongly support the Open Access Initiative. Abstract and full text of the article published by Psychosophia are freely accessible to everyone immediately after publication. This is an Open Access article distributed under the terms of the Creative Commons Attribution License, which permits unrestricted use, distribution, and reproduction in any medium, provided the original work is properly cited.

| Psychosophia Vol. 2, No. 1 (2020)

Page 32 of 15

Submission Date Review Date Publish Date
March 02, 2020 April 07, 2020 : June 01, 2020 
pembelajaran PAI menggunakan media animasi adalah kemudahan dari media animasinya sendiri untuk digunakan dan penayangan media animasi yang membuat anak tunagrahita mudah memahami materi PAI yang disampaikan, seperti materi rukun Islam. Faktor penghambatnya yaitu memerlukan biaya untuk mengakses media animasi. 4) Tingkat keberhasilannya ditunjukkan pada nilai siswa tunagrahita yaitu melalui laporan hasil belajar siswa tunagrahita yang mendapatkan nilai rata-rata 80 dari KKM yang ditetapkan yaitu 75 .

Kata kunci; media animasi, Pendidikan Agama Islam, tunagrahita. 
Pendahuluan

Anak berkebutuhan khusus dikategorikan menjadi dua, yakni mereka yang memiliki kemampuan diatas ratarata dan mereka yang memiliki kemampuan di bawah rata-rata, baik dari segi inteligensi, fisik, bakat minat, dan sebagainya. Menurut UU Sisdiknas No. 20 Th. 2003 jenis pendidikan bagi anak berkebutuhan khusus adalah pendidikan khusus. Pendidikan khusus merupakan pendidikan bagi peserta didik yang memiliki tingkat kesulitan dalam memiliki proses pembelajaran dikarenakan kelainan fisik, emosional, mental, sosial, dan atau memiliki potensi kecerdasan dan bakat istimewa. Salah satu anak yang termasuk kategori anak berkebutuhan khusus adalah anak tunagrahita.

Berdasarkan hasil observasi awal ke SLB Angkasa Lanud Sulaiman diperoleh data tentang masalah yang dihadapi tunagrahita. Data tersebut diambil dari hasil wawancara dengan guru PAI tunagrahita Ibu Yayu Khoerul Bariyyah yang mengatakan kesulitan anak tunagrahita dalam belajar PAI yaitu sulit menghafal materi-materi PAI yang disampaikan, sulit membaca dan menulis materi PAI yang disampaikan, sehingga seringkali guru mengulang materi yang sudah disampaikan dan disampaikan lagi pada pertemuan-pertemuan selanjutnya sampai anak tunagrahita tersebut dapat memahami dan menghafal materi PAI yang disampaikan. Pembelajaran yang dilakukan di SLB Angkasa Lanud Sulaiman masih berupa pembelajaran klasikal, seperti menulis di papan tulis, menghafal materi dengan mengulang penjelasan guru, sehingga siswa tunagrahita sering kali merasa jenuh dan meminta untuk keluar kelas, bahkan ada juga yang sudah tidak fokus untuk belajar sehingga berlarian di dalam kelas.

Penelitian ini di lakukan pada kelas 6 SDLB Angkasa Lanud Sulaiman dengan banyak siswa 7 orang, namun penelitian hanya dilakukan pada 4 siswa tunagrahita, karena 2 orang siswa tunagrahita yang ada di dalam kelas tersebut adalah tunagrahita mampu rawat, anak tunagrahita mampu rawat memilik kecerdasan sangat rendah sehingga ia tidak mampu mengurus diri sendiri atau bersosialisasi sehingga diperlukan tenaga pendidik khusus anak luar biasa untuk menangani tunagrahita mampu rawat tersebut. Sedangkan 4 orang siswa tunagrahita yang terlibat dalam penelitian adalah tunagrahita mampu didik atau anak tunagrahita mampu didik tidak mampu mengikuti program pada sekolah biasa, tetapi ia masih memiliki kemampuan yang dapat dikembangkan melalui pendidikan walaupun hasilnya tidak maksimal.

Melalui hasil wawancara awal yang dilakukan bersama Ibu Yayu Khoerul Bariyah, S.Pd selaku guru PAI tunagrahita di SLB Angkasa Lanud Sulaiman juga menjelaskan bahwa 4 orang siswa yang mampu didik itu tidak semua memiliki kemampuan belajar yang sama, meskipun mereka mampu mengikuti pembelajaran, ada satu diantara mereka yang harus menghafal materi PAI dengan bimbingan guru hingga akhir, satu diantara mereka yang mengalami multiple handicap (dua kelainan atau lebih), namun dalam penyerapan materi PAI yang disampaikan mudah menerima hanya saja penyebutannya yang kurang jelas, dan dua siswa tunagrahita lainnya mampu melafalkan materi PAI dengan jelas. 
Menghadapi permasalahan yang dialami anak tunagrahita dalam proses pembelajaran PAI hendaknya perlu diupayakan solusi untuk mempermudah anak tunagrahita dalam belajar PAI yaitu dengan memperhatikan media pembelajaran. Media pembelajaran merupakan faktor yang dapat mempengaruhi keefektifan proses pembelajaran. Terdapat beberapa media pembelajaran yang bisa digunakan dalam proses pembelajaran, yaitu media visual, media audio, media audio-visual, dan multimedia.

Penggunaan media pembelajaran harus disesuaikan dengan tujuan pembelajaran yang diharapkan, karena tidak ada satu media yang cocok untuk semua tujuan pembelajaran. Untuk itu, guru hendaknya mengetahui berbagai jenis dan contoh media beserta kelebihan dan kekurangannya. Sehingga ketika kegiatan pembelajaran berlangsung, media yang digunakan bisa menjadi perantara yang pas untuk menyampaikan materi atau informasi untuk pelajaran tertentu pula, termasuk pada pembelajaran agama Islam.

Salah satu media yang bisa digunakan sebagai alternatif pembelajaran PAI yaitu melalui media pembelajaran animasi. Animasi merupakan media yang menggabungkan antara audio dan visual dengan penceritaan cerita menggunakan langkah animasi atau seringpula disebut dengan kartun. Penggunaan animasi dalam pembelajaran terpadu merupakan langkah untuk memberikan kemudahan bagi guru dalam mengaplikasikan materi pembelajaran sesuai dengan peran dan fungsinya. Animasi menggambarkan objek yang bergerak agar kelihatan hidup. Membuat animasi berarti menggerakkan gambar seperti, kartun, lukisan, tulisan, dan lain- lain. (Sutopo, 2002)

$$
\text { Media animasi memiliki }
$$

kemampuan untuk dapat memaparkan sesuatu yang rumit atau komplek untuk dijelaskan dengan hanya gambar dan kata-kata saja. Dengan kemampuan ini maka animasi dapat digunakan untuk menjelaskan suatu materi yang secara nyata tidak dapat terlihat oleh mata, dengan cara melakukan visualisasi maka materi yang dijelaskan dapat tergambarkan.

Media animasi memiliki banyak warna-warna cerah dan ragam karakter animasi dilukis sedemikian rupa sehingga anak-anak tidak terkecuali juga dengan anak berkebutuhan khusus tunagrahita tertarik dengan berbagai bentuk animasi. Selain itu bagi anak tunagrahita yang belum lancar dalam membaca, mereka bisa mendengarkan audio atau suara yang diputar dalam video animasi. Sehingga selain melihat tampilan gambar gerakan, anak juga bisa mendengarkan audionya.

Pada media animasi terdapat banyak warna dan gambar yang akan mempengaruhi otak. Otak manusia lebih suka dengan sesuatu yang bergambar dan berwarna. Karena gambar bisa memiliki sejuta arti sedangkan warna akan membuat segala sesuatu menjadi lebih hidup sehingga jika disatukan akan menghasilkan hal positif. (Wahyudi, 2017, pp. 384-391) Sehingga media animasi dapat diupayakan menjadi solusi dalam pembelajaran PAI untuk anak tunagrahita di SLB Angkasa Lanud Sulaiman.

Hasil penelitian yang relevan dilakukan oleh Nurian Anggraini, 
Universitas Sebelas Maret, 2017. Dalam Tesis yang berjudul "Pengembangan Multimedia Interaktif Macromedia Flash pada Pembelajaran Agama Islam untuk Meningkatkan Motivasi Belajar dan Daya Ingat Anak Tunagrahita." Hasil penelitian menunjukkan bahwa pelaksanaan pembelajaran agama Islam masih berlangsung secara konvensional, guru membutuhkan inovasi baru yang sesuai dengan karakteristik anak tunagrahita, pengembangan multimedia interaktif meliputi penetapan materi pokok dan tujuan pembelajaran, pembuatan flowchart dan story board, pembuatan multimedia interaktif beserta buku panduan penggunaannya, tingkat validitas produk termasuk pada kategori sangat baik, tingkat keterbacaan produk termasuk pada kategori sangat baik, tingkat kelayakan produk termasuk pada kategori sangat baik, dan multimedia interaktif efektif dalam meningkatkan motivasi belajar dan daya ingat anak tunagrahita dengan tingkat probabilitas $5 \%$.

\section{Metode}

Penelitian ini menggunakan jenis data kualitatif yaitu data yang berupa kata-kata verbal dan bukan berbentuk angka. (Sugiyono, 2010) Data kualitatif dalam penelitian ini berkenaan dengan masalah yang akan dibahas yakni penggunaan media animasi pada pembelajaran Pendidikan Agama Islam untuk anak tunagrahita di SLB Angkasa Lanud Sulaiman. Adapun yang dimaksud sumber data dalam penelitian ini adalah subjek yang dapat memberikan keterangan guna dijadikan data penelitian. Sumber data penelitian ini dibagi menjadi dua jenis yaitu Sumber Data Primer dan sumber data sekunder.

Data primer adalah sumber data yang langsung memberikan data kepada pengumpul data. (Sugiyono, 2010) Data ini bersumber dari ucapan dan tindakan yang diperoleh peneliti dari hasil wawancara, dokumentasi, dan observasi atau pengamatan langsung pada objek selama kegiatan penelitian di lapangan. Dalam penelitian ini informan penelitian dipilih melalui purposive sampling dan snowball sampling. Purposive sampling adalah teknik pengambilan data dengan pertimbangan tertentu. Pertimbangan dalam hal ini yakni orang-orang yang memiliki kriteria dan dianggap paling mengetahui tentang topik penelitian.

Sedangkan snowball sampling adalah teknik pengambilan sampel sumber data, yang awalnya hanya dalam jumlah kecil, kemudian berkembang menjadi dalam jumlah besar. Hal ini dilakukan karena dari jumlah sumber data yang ada dirasa belum mampu memberikan data yang memuaskan, maka kemudian peneliti akan mencari sumber lain untuk dijadikan sebagai sumber data penelitian. (Sugiyono, 2010)

Pemilihan subjek penelitian ini dimaksudkan agar dapat mempresentasikan data terkait penggunaan media animasi pada pembelajaran Pendidikan Agama Islam untuk anak tunagrahita di SLB Angkasa Lanud Sulaiman. Berdasarkan uraian tersebut, maka sumber data primer dalam penelitian ini adalah Kepala Sekolah, guru Pendidikan Agama Islam, serta peserta didik di SLB Angkasa Lanud Sulaiman.

Data sekunder adalah data yang diperoleh dari dokumen-dokumen resmi, buku-buku, hasil penelitian yang 
berwujud laporan, buku harian dan sebagainya. Sumber data sekunder adalah sumber data di luar kata-kata dan tindakan yakni sumber data tertulis. Sumber data sekunder merupakan sumber data pelengkap yang berfungsi melengkapi data yang dibutuhkan oleh data primer. Dilihat dari sumber datanya, maka sumber data sekunder dalam penelitian ini adalah berupa buku, majalah ilmiah, jurnal, internet, sumber dari arsip, dokumen pribadi, dan dokumen resmi yang berkaitan dengan efektivitas penggunaan media animasi pada pembelajaran Pendidikan Agama Islam untuk anak tunagrahita di SLB Angkasa Lanud Sulaiman.

Metode yang digunakan dalam penelitian ini adalah metode deskriptif yakni metode penelitian yang menggambarkan sifat-sifat atau karakter individu, keadaan, gejala, atau kelompok tertentu (Hasan, 2002). Dengan menggunakan metode ini, seluruh fakta, gejala, serta peristiwa yang terjadi di lapangan terkait dengan penggunaan media animasi pada pembelajaran pendidikan agama Islam untuk anak tunagrahita dideskripsikan berdasarkan hasil analisis data yang telah dikumpulkan.

Adapun teknik pengumpulan data yang digunakan dalam penelitian ini ialah sebagai berikut:

Observasi atau pengamatan adalah metode pengumpulan data di mana peneliti mencatat informasi sebagaimana yang disaksikan selama penelitian. Penyaksian terhadap peristiwa-peristiwa itu bisa dengan melihat, mendengarkan, merasakan, yang kemudian dicatat seobjektif mungkin (Gulo, 2010).
Observasi dalam penelitian ini digunakan untuk memperoleh data berupa kondisi objektif SLB Angkasa Lanud Sulaiman, implementasi pembelajaran PAI, serta keadaan anak tunagrahita di SLB Angkasa Lanud Sulaiman.

Wawancara adalah bentuk komunikasi langsung antara peneliti dan responden. Wawancara dilakukan secara langsung dengan tanya jawab dalam tatap muka, sehingga gerak-gerik responden merupakan media yang melengkapi keterangan verbal (Gulo, 2010). Wawancara digunakan dalam penelitian ini untuk menggali informasi sedalamdalamnya dari sumber-sumber data primer sehingga hasil penelitian ini akan lebih akurat.

Dokumen adalah catatan tertulis tentang berbagai kegiatan atau peristiwa pada waktu yang lalu (Gulo, 2010). Dokumentasi dilakukan dalam rangka melengkapi data penelitian yang diperlukan. Di dalam penelitian ini peneliti akan menganalisis beberapa dokumen terkait dengan pembahasan penelitian yakni penggunaan media animasi pada pembelajaran Pendidikan Agama Islam untuk anak tunagrahita di SLB Angkasa Lanud Sulaiman berupa dokumen Rencana Pelaksanaan Pembelajaran (RPP) mata pelajaran PAI dan silabusnya serta dokumen lain yang berhubungan dengan pembahasan tersebut.

Analisis data dalam penelitian ini menggunakan teori dari Miles dan Huberman sebagaimana yang dikutip oleh Sugiyono yang menyatakan bahwa analisis data dalam penelitian kualitatif dilakukan dalam tiga tahap yaitu reduksi 
data, display data, dan verifikasi data (Sugiyono, 2015).

Reduksi data, pada tahap ini data yang terkumpul diolah dengan tujuan untuk menemukan hal-hal pokok dalam menganalisis penggunaan media animasi pada pembelajaran Pendidikan Agama Islam untuk anak tunagrahita di SLB Angkasa Lanud Sulaiman.

Display data, pada tahap ini peneliti membuat rangkuman temuan penelitian secara sistematis sehingga pola dan fokus pembahasan diketahui melalui kesimpulan data tersebut kemudian diberi makna yang relevan dengan fokus penelitian.

Verifikasi data, dalam tahap ini peneliti melakukan pengujian atau kesimpulan yang telah diambil dan membandingkan dengan teori-teori yang relevan serta petunjuk dan pembinaan pemantapan penguji kesimpulan dihubungkan dengan data awal melalui kegiatan memberi check, sehingga menghasilkan suatu penelitian yang bermakna.

Setelah data dianalisis kemudian diuji kredibilitasnya. Uji kredibilitas ini digunakan untuk memastikan bahwa data yang dtemukan benar-benar valid atau tidak. Adapun teknik untuk menguji keabsahan data dalam penelitian ini digunakan triangulasi dan bahan referensi.

Triangulasi adalah teknik pemeriksaan data yang memanfaatkan sesuatu yang lain di luar data itu untuk keperluan pengecekan atau sebagai pembanding terhadap data. Triangulasi yang digunakan dalam penelitian ini adalah triangulasi sumber dan triangulasi metode. Triangulasi sumber ialah membandingkan dan mengecek balik derajat kepercayaan suatu informasi yang diperoleh melalui sumber yang sama dalam waktu yang berbeda. Sedangkan triangulasi metode adalah setelah data yang dikumpulkan dengan menggunakan metode tertentu untuk kemudian dilakukan pengekan dengan metode yang lain. Misalnya data yang dikumpulkan dengan menggunakan teknik wawancara, kemudian dicek dengan menggunakan metode observasi atau dengan menggunakan analisis dokumen.

Bahan referensi adalah adanya pendukung untuk membuktikan data yang telah ditemukan oleh peneliti. Misalnya data hasil wawancara perlu didukung dengan adanya rekaman wawancara, atau gambaran suatu keadaan perlu didukung dengan foto-foto (Sugiyono, 2015).

\section{Hasil dan Pembahasan}

Validasi dilakukan oleh ahli terkait yakni ahli media dan guru PAI di Sekolah Luar Biasa. Data hasil penelitian pada tahap validasi produk adalah sebagai berikut:

1) Validasi media dilakukan oleh ahli teknologi yaitu Pak Faundry Amrul Ma'ruf. Data yang diperoleh oleh ahli media digunakan sebagai pedoman melakukan revisi pada media animasi yang dikembangkan.

2) Validasi materi dilakukan oleh ahli agama Islam di SLB Angkasa Lanud Sulaiman yaitu Ibu Yayu Khoerul Bariyyah. Data yang diperoleh oleh ahli materi digunakan sebagai pedoman melakukan revisi pada multimedia yang dikembangkan.

Setelah melihat dan mencoba media animasi agama Islam materi rukun Islam, ahli media dan ahli materi di 
sekolah luar biasa bidang ketunagrahitaan memberikan penilaian sebagai berikut: Hasil dapat dihitung dengan rumus:

Hasil $=\frac{\text { Total skor } \text { yang diperoleh }}{\text { Skor Maksimum }} \times 100 \%$

Kategori kelayakan berdasarkan kriteria sebagai berikut (Arikunto \& Jabar, 2009):

Tabel 1

Kriteria Penilaian

\begin{tabular}{lll}
\hline No & Interval Skor & $\begin{array}{l}\text { Kriteria } \\
\text { Penilaian }\end{array}$ \\
\hline 1 & $81-100$ & Sangat Baik \\
2 & $61-80$ & Baik \\
3 & $41-60$ & Cukup \\
4 & $21-40$ & Kurang \\
5 & $0-20$ & Sangat Kurang \\
\hline
\end{tabular}

Data yang diperoleh pada tahap validasi produk, dianalisis menggunakan teknik analisis statistik deskriptif. Pada tahap validasi produk pengumpulan data menggunakan instrument skala likert dengan 5 kriteria penilaian, yakni sangat baik (SB) bernilai 5, baik (B) bernilai 4, cukup (C) bernilai 3, kurang baik (KB) bernilai 2, dan tidak baik (TB) bernilai 1 . Selanjutnya perolehan nilai dikategorikan menjadi sangat baik, baik, cukup, kurang, dan sangat kurang.

\section{Penilaian Media Animasi dari Ahli Media}

Hasil perolehan data pada tahap uji validasi produk adalah sebagai berikut:

a. Perolehan data menurut penilaian ahli media. Data yang diperoleh dari media pada aspek kelayakan isi mendapat jumlah skor total 43 dengan total nilai akhir sebanyak 95,5, pada aspek kebahasaan jumlah skor total 24 dengan total nilai akhir sebanyak 96, pada aspek penyajian mendapat jumlah skor total 32 dengan total nilai akhir sebanyak 91,4, dan pada aspek kegrafikaan mendapat jumlah skor total 28 dengan total nilai akhir 93,3. secara keseluruhan perolehan jumlah skor total dari ahli media dari 27 item soal adalah sebanyak 127 dengan total nilai akhir 94,1 dan jika dikonversikan kedalam tabel penilaian hasil uji coba ahli termasuk pada kriteria "sangat baik".

b. Perolehan data menurut penilaian ahli materi PAI di SLB Lanud Sulaiman bidang ketunagrahitaan. Data yang diperoleh dari ahli materi pada aspek kelayakan isi mendapat jumlah skor total 39 dengan total nilai akhir sebanyak 86,6, pada aspek kebahasaan mendapat jumlah skor total 21 dengan total nilai akhir sebanyak 84, pada aspek penyajian mendapat jumlah skor total 32 dengan total nilai akhir sebanyak 91,4, dan pada aspek kegrafikaan mendapat jumlah skor total 28 dengan total nilai akhir 93,3. Secara keseluruhan perolehan jumlah skor total dari ahli media dari 27 item soal adalah sebanyak 120 dengan total nilai akhir 88,8 dan jika dikonversikan kedalam tabel penilaian hasil uji coba ahli termasuk pada kriteria "sangat baik".

Secara keseluruhan data yang diperoleh melalui validasi produk oleh ahli dapat disimpulkan bahwasanya produk yang dikembangkan berupa media animasi materi rukun Islam termasuk pada kategori sangat baik dan sudah bisa digunakan dengan sedikit revisi. 


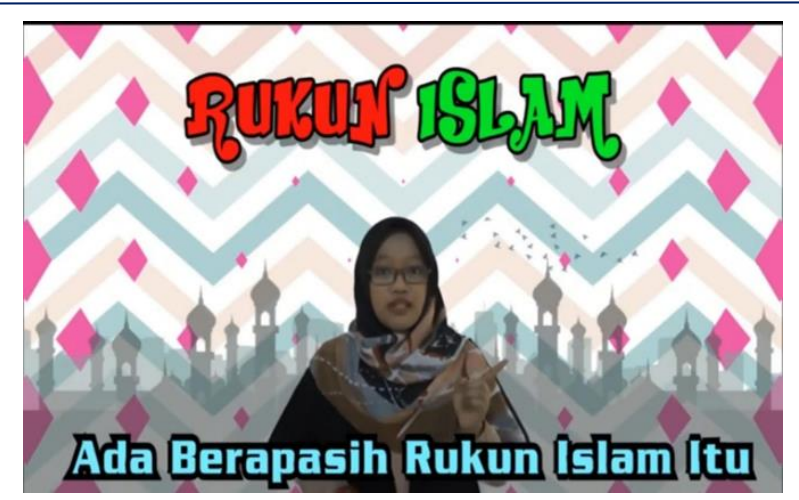

Gambar 1. Tampilan Form Memasuki Materi

Halaman ini memberikan informasi mengenai materi rukun Islam yang akan dipelajari. Guru menjelaskan terlebih dahulu mengenai materi rukun Islam sebelum media animasi diputar, kemudian setelah guru menjelaskan materi rukun Islam, media animasi diputar dan dipertontonkan pada anak tunagrahita. Pada form ini animasi hanya berisikan mengajak untuk belajar mengenal rukun Islam dengan kalimat ; Ayo adik-adik semua kita belajar mengenal rukun Islam, ada berapasih rukun Islam itu?

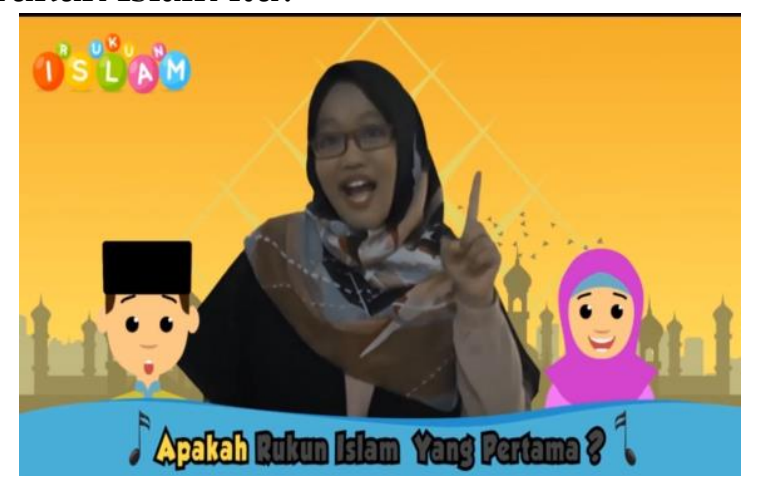

Gambar 2. Tampilan Form Materi

Guru menjelaskan menjelaskan materi rukun Islam perpoint dengan mengulangnya tiga kali tanpa menggunakan media animasi. Kemudian media animasi diputar dan murid mengikuti bernyanyi bersama hingga lima kali bernyanyi bersama mengenai rukun Islam.
Lirik dari lagu rukun Islam itu adalah:

Apakah rukun Islam yang pertama?

Jawab: Syahadat

Apakah rukun Islam yang kedua?

Jawab: Sholat

Ketiganya?

Jawab: Puasa

Keempat?

Jawab: Bayar zakat

Kelima?

Jawab: Pergi haji naik pesawat.

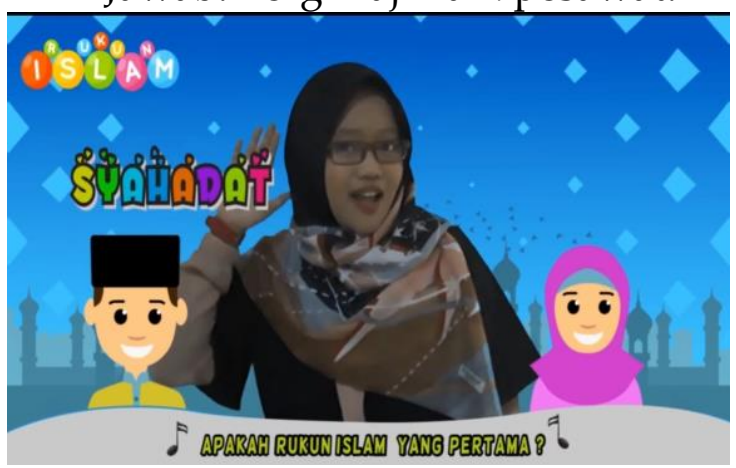

Gambar 3. Materi Rukun Islam yang

Jawabannya dikosongkan/ tampilan form

evaluasi

Pada halaman ini, berisikan poinpoin rukun Islam yang dikosongkan jawabannya, supaya anak tunagrahita dapat mengikuti ulang hafalan yang sudah dipraktekan. Di dalam animasi tersebut hanya terdapat pertanyaanpertanyaan dari materi rukun Islam dengan dinyanyikan. Guru meminta siswa tunagrahita untuk memperhatikan pertanyaan dari media animasi yang ditampilkan kemudian siswa menjawab bagian yang kosong.

Apakah rukun Islam yang pertama?

Jawab: .......

Apakah rukun Islam yang kedua?

Jawab: ......

Ketiganya?

Jawab: ..... 
Keempat?

Jawab: ......

Kelima?

Jawab: .....

Faktor pendukung dari penggunaan media animasi yang membuktikan media animasi menjadi media yang layak pakai untuk mencapai pembelajaran yang lebih efektif. Hal itu dibuktikan melalui hasil angket dari 5 orang guru tunagrahita dan 5 orang anak tunagrahita, yaitu: (Hasil Angket dari 5 Orang Guru Tunagrahita SLB Angkasa Lanud Sulaiman, n.d.) Total yang sangat setuju 35 poin. Total yang setuju 35 poin. Total yang cukup 10 poin. Kurang setuju 0 poin. Tidak setuju 0 poin. Dapat disimpulkan media animasi sangat mendukung dalam pembelajaran PAI untuk anak tunagrahita.

Hasil angket dari 5 orang tunagrhita yaitu: Total poin 65 dari angket anak tunagrahita yang menyetujui bahwa media animasi sangat menyenangkan dan memudahkan untuk digunakan dalam pembelajaran PAI. Dapat disimpulkan dari hasil angket di atas, bahwa media animasi lebih mudah digunakan dalam bentuk penggunaannya dan mudah diterima dalam penyampaiannya, materi yang disampaikanpun mudah dipahami, dan yang terpenting adalah menyenangkan, untuk supaya anak tunagrahita merasa tidak bosan dalam pembelajaran.

Hasil nilai yang didapat, bahwa sanya anak tunagrahita mengalami peningkatan belajar melalui penggunaan media animasi yang tepat dan bimbingan guru dan mendapatkan hasil nilai di atas Kriteria Ketuntasan Minimal (KKM) PAI yaitu 75 dan mendapatkan nilai dengan rata-rata 80. Dan penilaian yang didapat lebih banyak melalui hafalan, bukan bentuk tulisan. Karena mengingat karakteristik anak tunagrahita yang memiliki kesulitan belajar dalam menulis, membaca dan bahkan menghafal, namun dalam hal menghafal untuk tunagrahita mampu didik ini, dapat diupayakan dengan cara mengulang-ulang bentuk materi yang disampaikan.

Perencanaan

Pembelajaran

Pendidikan Agama Islam menggunakan Media Animasi untuk Tunagrahita memperhatikan karakteristik siswa tunagrahita yang dalam mengikuti pembelajaran mudah merasa bosan, sulit dalam berkonsentrasi, dan rentang perhatian yang mudah teralih. Hal ini sejalan dengan pendapat Prasadio yang menyatakan bahwa karakteristik anak tunagrahita usia sekolah adalah kesulitan mengikuti hampir semua pelajaran, prestasi yang kurang, kebisaaan kerja yang kurang baik, perhatian yang mudah beralih, kemampuan motorik yang kurang, perkembangan bahasa yang jelek, dan kesulitan menyesuaikan diri (Hernawati, 2007).

Tunagrahita sangatlah lambat daya tangkapnya, penggunaan media pembelajaran dalam bentuk konkrit sangat menarik karena anak tunaghrahita cepat bosan dan mudah beralih perhatianya, sehingga perlu adanya media yang menarik, konkrit dan mudah dipahami oleh anak tunagrahita (Meimulyani, 2013). Selain itu faktor yang menyebabkan anak mengalami ketunagrahitaan. Beberapa faktor yang dikemukakan oleh Wantah adalah sebagai berikut (Wantah, 2007): 


\section{a. Keturunan}

Berdasarkan pada penelitian tentang anak tunagrahita, disebutkan bahwa kira-kira 5\% anak tunagrahita disebabkan oleh faktor keturunan. Hal ini disebabkan oleh kelainan yang diwariskan pada gen seperti fragile $X$ syndrom, kerusakan salah satu gen seperti phenylketonuria.

b. Sebelum lahir

Beberapa anak tunagrahita mengalami keterbelakangan mental disebabkan karena pada waktu hamil usia kandungan 12 minggu ibu minum alkohol. Selain itu, infeksi penyakit seperti gangguan rubella juga bisa menjadi penyebab ketunagrahitaan pada anak.

c. Kerusakan pada waktu lahir

Kerusakan pada waktu lahir bisa disebabkan oleh proses melahirkan yang sulit sehingga harus menggunakan peralatan untuk membantu agar anak dapat lahir.

d. Penyakit dan luka-luka pada masa kanak- kanak

Beberapa penyakit yang diderita pada masa kanak-kanak juga dapat menyebabkan keterbelakangan mental. Jenis penyakitnya seperti hyperthyroidism, whooping cough, chikenpos, meales dan hib dapat menyebabkan ketunagrahitaan apabila tidak ditangani dengan cepat.

e. Faktor lingkungan

Keadaan lingkungan akan sangat mempengaruhi tumbuh kembang anak. Walaupun anak dilahirkan normal akan tetapi apabila tidak diperhatikan maka anak akan menjadi keterbelakangan mental. Contohnya tidak memberikan bayi rangsangan fisik dan mental yang diperlukan selama proses tumbuh kembang, sehingga bayi tersebut akan terganggu proses tumbuh kembangnya dan mengalami keterbelakangan mental dalam beberapa hal. Selain itu kekurangan gizi, lingkungan yang tidak sehat juga ikut andil dalam menjadikan anak terbelakang mental.

Gangguan dalam bidang kognitif merupakan masalah besar bagi anak tunagrahita, beberapa hambatan yang tampak pada anak tunagrahita dari segi kognitif dan menjadi karakteristik mereka yaitu: (Effendi, 2006, p. 98)

a. Cenderung memiliki kemampuan berfikir konkret dan sukar berfikir.

b. Mengalami kesulitan dalam konsentrasi.

c. Kemampuan sosialnya terbatas.

d. Tidak mampu menyimpan instruksi yang sulit.

e. Kurang mampu menganalisis dan menilai kejadian yang dihadapi.

f. Pada tunagrahita mampu didik, prestasi tertinggi bidang baca, tulis, hitung tidak lebih dari anak normal setingkat kelas III-IV SD.

Keterbatasan daya pikir yang dialami anak tunagrahita menyebabkan mereka sulit mengontrol perilakunya dalam kegiatan sehari-hari. Mereka kurang memahami apakah perilaku mereka wajar atau tidak, baik perilaku yang berlebihan maupun tidak serasi

Dari faktor-faktor penyebab tunagrahita di atas, peneliti mengupayakan sebuah media pembelajaran untuk mempermudah anak tunagrahita dalam mengikuti pembelajaran PAI berupa materi rukun Islam yaitu melalui media animasi yang mana media animasi ini merupakan satu bentuk presentasi bergambar yang paling menarik, yang berupa simulasi gambar 
bergerak yang menggambarkan perpindahan atau pergerakan suatu objek (Sukiyasa, 2013).

Penggunaan animasi dalam proses pembelajaran sangat membantu dalam meningkatkan efektifitas dan efisiensi proses pengajaran, serta hasil pembelajaran yang meningkat. Selain itu, penggunaan media pembelajaran khususnya animasi dapat meningkatkan daya tarik, serta motivasi siswa dalam mengikuti proses pembelajaran. Berdasarkan beberapa pendapat diatas dapat disimpulkan bahwa media animasi adalah media audio visual yang merupakan kumpulan gambar bergerak dan suara berisikan materi pembelajaran yang ditampilkan melalui media elektronik projektor sebagai usaha untuk menciptakan pembelajaran yang aktif dan menyenangkan.

Animasi pada saat ini banyak dimanfaatkan untuk berbagai kebutuhan dalam berbagai kegiatan. Animasi dibangun berdasarkan manfaatnya sebagai media yang digunakan untuk berbagai keperluan, diantaranya media hiburan, media presentasi, media iklan, media ilmu pengetahuan, media bantu, atau media pelengkap, yaitu (Munir, 2015):

1. Media hiburan, animasi digunakan untuk menghibur pengguna animasi tersebut, sehingga memberikan kepuasan. Animasi sebagai media hiburan, sebagai produk dagangan yang memiliki harga jual. Sebagai media hiburan, animasi digarap sebagai project, contohnya film, video klip, games dan lain-lain.

2. Media presentasi, animasi digunakan untuk menarik perhatian para audien atau peserta presentasi terhadap materi yang disampaikan oleh presenter. Animasi pada media presentasi membawa suasana presentasi menjadi tidak kaku dan bervariasi. Fungsi dalam presentasi diantaranya (Munir, 2015) :

a. Menarik perhatian dengan adanya pergerakan dan suara yang selaras.

b. Memperindah tampilan presentrasi.

c. Memudahkan susunan presentasi.

d. Mempermudah penggambaran dari suatu materi.

3. Media iklan, animasi dibangun dengan sedemikian rupa agar penonton tertarik untuk membeli atau memiliki atau mengikuti apa yang disampaikan dalam alur cerita dari animasi tersebut. Contohnya iklan produk, penyuluhan kesehatan, iklan layanan masyarakat.

4. Media ilmu pengetahuan, animasi memiliki kemampuan untuk dapat menjelaskan sesuatu yang rumit hanya dengan gambar atau kata-kata saja. Dengan kemampuan ini maka animasi dapat digunakan untuk menelaskan suatu materi yang secara nyata tidak dapat terlihat oleh mata, dengan cara melakukan visualisasi maka materi yang dijelaskan dapat tergambarkan. Selain itu animasi sebagai media ilmu pengetahuan dapat dijadikan sebagai perangkat bahan ajar yang siap kapan saja untuk mengajarkan materi yang telah dianimasikan, terutama dengan adanya teknologi interaktif, baik melalui perangkat computer ataupun perangkat elektronik lainnya. Pada perangkat computer ini dikenal dengan istilah CAI (Computer Aided Instruction).

5. Media bantu, animasi digunakan sebagai perangkat penuntun atau 
petunjuk dalam melakukan sesuatu. Sebagai media bantu, animasi akan menonjolkan, memberikan daya tarik atau memunculkan fokus baru terhadap sesuatu yang perlu dibantu. Contohnya petunjuk tata cara penggunaan produk.

6. Media pelengkap, animasi digunaka sebagai pelengkap atau hiasan pada suatu tampilan yang digunakan untuk mempercantik atau menarik pada objek yang ditampilkan. Contohnya tombol animasi, banner, bingkai atau frame, dan tulisan.

\section{Simpulan dan Saran \\ Simpulan}

Berdasarkan hasil penelitian dan pembahasan yang telah didiskripsikan adalah sebagai berikut:

1. Validasi produk media animasi pada pembelajaran PAI materi rukun Islam yaitu Perolehan data menurut penilaian ahli media. Berdasarkan data yang diperoleh dari media pada aspek kelayakan isi mendapat nilai akhir sebanyak 95,5, pada aspek kebahasaan mendapat nilai akhir sebanyak 96, pada aspek penyajian mendapat nilai akhir sebanyak 91,4, dan pada aspek kegrafikaan nilai akhir 93,3. Secara keseluruhan perolehan nilai dari ahli media dari 27 item soal adalah 94,1 dan jika dikonversikan kedalam tabel penilaian hasil uji coba ahli termasuk pada kriteria "sangat baik".

Perolehan data menurut penilaian ahli materi PAI di SLB Angkasa Lanud Sulaiman bidang ketunagrahitaan. Data yang diperoleh dari ahli materi pada aspek kelayakan isi mendapat nilai akhir sebanyak 86,6 , pada aspek kebahasaan mendapat nilai akhir sebanyak 84, pada aspek penyajian mendapat nilai akhir sebanyak 91,4, dan pada aspek kegrafikaan mendapat nilai akhir 93,3. Secara keseluruhan perolehan nilai dari ahli media dari 27 item soal adalah 88,8 dan jika dikonversikan kedalam tabel penilaian hasil uji coba ahli termasuk pada kriteria "sangat baik".

2. Implementasi penggunaan media animasi pada pembelajaran PAI untuk tunagrahita mengikuti langkah-langkah pada kegiatan belajar yang tercantum di dalam rencana pelaksanaan pembelajaran yang sudah disesuaikan dengan kriteria anak tunagrahita yaitu: Peserta didik menyimak penjelasan guru tentang rukun Islam, Peserta didik mengamati animasi tentang rukun Islam, Peserta didik menanggapi dengan bahasanya dari hasil pengamatan media animasi tentang rukun Islam, Masing-masing individu mengurutkan poin-poin rukun Islam, Masing-masing individu secara bergantian menyebutkan rukun Islam.

3. Faktor penggunaan media animasi diambil dari hasil angket dan wawancara bahwa media animasi lebih mudah digunakan dalam bentuk penggunaannya dan mudah diterima dalam penyampaiannya, materi yang disampaikanpun mudah dipahami, dan yang terpenting adalah menyenangkan, untuk supaya anak tunagrahita merasa tidak bosan dalam pembelajarannya.

4. Hasil Yang didapat bahwa sanya anak tunagrahita mengalami peningkatan belajar melalui penggunaan media 
animasi yang tepat dan bimbingan guru dan mendapatkan hasil nilai di atas Kriteria Ketuntasan Minimal (KKM) PAI yaitu 75 dan mendapatkan nilai dengan rata-rata 80. Dan penilaian yang didapat lebih banyak melalui hafalan, bukan bentuk tulisan. Karena mengingat karakteristik anak tunagrahita yang memiliki kesulitan belajar dalam menulis, membaca dan bahkan menghafal, namun dalam hal menghafal untuk tunagrahita mampu didik ini, dapat diupayakan dengan cara mengulang-ulang bentuk materi yang disampaikan.

\section{Saran}

Berdasarkan simpulan dan hasil penelitian ini, peneliti memberikan saran sebagai berikut:

1. Hendaknya pembelajaran agama Islam bagi anak tunagrahita dilaksanakan dengan menggunakan media pembelajaran yang variatif, salah satunya adalah media audio visual/ multimedia interaktif animasi.

2. Hasil penelitian berupa media animasi untuk materi PAI bagi peserta didik tunagrahita bisa terus digunakan sebagai media pembelajaran dalam pembelajaran PAI kepada peserta didik tunagrahita.

3. Sebaiknya ketika menggunakan media animasi sebagai media pembelajaran, hendaknya pembelajaran harus dibarengi dengan praktek langsung agar lebih efektif dan tujuan pembelajaran bisa dicapai dengan optimal. 


\section{Daftar Pustaka}

Effendi, M. (2006). Pengantar Psikopedagogik Anak Berkelainan. Jakarta: Bumi Aksara.

Hasil Angket dari 5 Orang Guru Tunagrahita SLB Angkasa Lanud Sulaiman.

Hasil Angket dari 5 Orang Siswa Tunagrahita SLB Angkasa Lanud Sulaiman.

Kadek Sukiyasa, S. (2013). Pengaruh Media Animasi terhadap Hasil Belajar dan Motivasi Belajar Siswa Materi Sistem Kelistrikan Otomotif. Jurnal Pendidikan Vokasi, 3(1), 126-137.

M. Iqbal Hasan. (2002). Pokok-Pokok Materi Metodologi Penelitian dan Aplikasinya. Jakarta: Ghalia Indonesia.

Meimulyani, Y. \& C. (2013). Media Pembelajaran Adaptif Bagi Anak Berkebutuhan Khusus. Jakarta Timur: PT. Luxima Metro Media.

Munir. (2015). Multimedia Konsep $\mathcal{E}$ Aplikasi dalam Pendidikan (M. T. Drs. Ruswandi dan Nurfitriansyah, ed.). Bandung: Alfabeta.

Sugiyono. (2010). Metode Penelitian Kuantitatif, Kualitatif, dan RED. Bandung: Alfabeta.

Sugiyono. (2015). Metode Penelitian Pendidikan. Bandung: Alfabeta.

Suharsimi Arikunto \& Cepi Safruddin Abdul Jabar. (2009). Evaluasi Program Pendidikan. Jakarta: Bumi Aksara.

Sutopo, A. H. (2002). Animasi dengan Macromedia Flash. Yogyakarta: Graha Ilmu.

W. Gulo. (2010). Metodologi Penelitian. Jakarta: PT Grasindo.

Wahyudi, H. (2017). Optimalisasi Daya Kerja Otak Melalui Pemanfaatan
Stimulan

Eksternal.

Jurnal

Pembelajaran Fisika, 5(4), 384-391.

Wantah, M. J. (2007). Pengembangan kemandirian anak tunagrahita mampu latih. Jakarta: Depdiknas.

Wardani, I.G.A.K, Hernawati, T, \& A. (2007). Pengantar Pendidikan Luar Biasa. Jakarta: Uniersitas Terbuka. 